\title{
Effects of microbial nutrient added on the degradation of living garbage and the water quality of leachate
}

\author{
Zhaoyuxin $^{1, a^{*}}$, Yangjing ${ }^{1, b}$, Zhangjunjun $^{1, c}$ \\ ${ }^{1}$ Key Laboratory of Songliao Aquatic Environment, Ministry of Education, Jilin Jianzhu University, \\ Changchun 130118, China

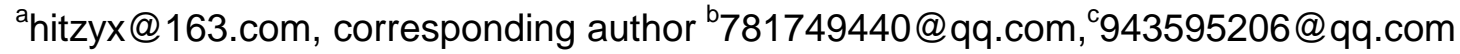

\begin{abstract}
Keywords: Living garbage; Degradation; Leachate; Nutrients
Abstract: In order to study the effects of microbial nutrients on the degradation of living garbage and the water quality of leachate, Vitamin $\mathrm{C}, \mathrm{KCl}, \mathrm{KH}_{2} \mathrm{PO}_{4}, \mathrm{NH}_{4} \mathrm{Cl}$ and a mixture of $\mathrm{KCl}, \mathrm{KH}_{2} \mathrm{PO}_{4}, \mathrm{NH}_{4} \mathrm{Cl}$ were added into anaerobic landfill garbage. The height of the settlement of each litter layer and concentration of leachate $\mathrm{COD}$ and ammonia nitrogen were investigated. Experimental results show that the Vitamin $\mathrm{C}, \mathrm{KCl}, \mathrm{KH}_{2} \mathrm{PO}_{4}, \mathrm{NH}_{4} \mathrm{Cl}$ and a mixture of $\mathrm{KCl}, \mathrm{KH}_{2} \mathrm{PO}_{4}, \mathrm{NH}_{4} \mathrm{Cl}$ can accelerate the degradation of living garbage, among which the vitamin $\mathrm{C}$ had the best effect on accelerating degradation.
\end{abstract}

\section{Introduction}

The degradation rate of living garbage is directly related to the stability of the landfill and the occupancy of the land ${ }^{[1]}$.In the design of living garbage sanitary landfill,which need to estimate the concentration of pollutants in the garbage leachate, living garbage gas production rate and degree of surface subsidence according to the degradation rate of the garbage ${ }^{[2 \sim 4]}$.In the design of the capacity of the landfill and the use of life, the degradation rate also has a certain effect, so the garbage degradation rate is very important parameters ${ }^{[5,6]}$. By adding Vitamin $\mathrm{C}, \mathrm{KCl}, \mathrm{KH}_{2} \mathrm{PO}_{4}, \mathrm{NH}_{4} \mathrm{Cl}$ and other nutrients to the anaerobic landfill garbage to accelerate the degradation of garbage landfill.It can increase the storage capacity, prolong the service life of landfill and reduce the use of landfill.In landfill land is increasingly reduced, waste transportation costs are too high today.The development of this technology undoubtedly has important economic significance and social significance.

\section{Experimental apparatus and method}

Experimental apparatus. The experimental apparatus is Seven inside diameter $0.10 \mathrm{~m}$ and high $2.00 \mathrm{~m}$ cylindrical organic glass columns, which is anaerobic landfill reactor.The garbage in the reactor is mainly taken from the fresh kitchen garbage of a university in Jilin. In addition, we add a number of waste paper, waste plastics, scrap metal and ceramic according to a certain weight percentage of mixed evenly. See Table 1.

Table 1 the composition of life rubbish in the experiment

\begin{tabular}{llllll}
\hline Waste composition & Kitchen Waste & waste paper & waste plastics & old metal & ceramics \\
weight percentage & About $75 \%$ & About $8 \%$ & About $5 \%$ & About 2\% & About 10\% \\
\hline
\end{tabular}

The main component of kitchen garbage were eggshell, beans, sweet potatoes, seasoning packet, leftovers (green pepper and egg), bread, cabbage leaves, conch shell silk, eggplant, garlic and so on. Seven of the waste in the reactor was broken and even mixed, the composition was almost identical. In these seven reactor, there are two of the reactors, which do not add any nutrients or vitamins. The remaining five are added to $1.0 \mathrm{~mol} / \mathrm{L} \mathrm{KCl}, \mathrm{KH}_{2} \mathrm{PO}_{4}, \mathrm{NH}_{4} \mathrm{Cl}$ and vitamin $\mathrm{C}$. and then some soil were covered at the top of the litter layer. The volume of the landfill is 4 times the size of its 
volume(national standards). The quality of garbage was $10 \mathrm{~kg}$ and the density of the garbage was $750 \mathrm{~kg} / \mathrm{m}^{3}$ in each reactor. In the experiment, the landfill leachate was produced by spraying the distilled water to the top which is collected through the bottom of the beaker. There was no reaction between the organic glass column and the landfill leachate and the bottom of the reactor was provided with a valve. A perforated pipe with a diameter of $10 \mathrm{~mm}$ in the middle position of the reactor was used to derive the landfill gas. Since the volume of the perforated tube was only $78.5 \mathrm{~mL}$ and the volume of the tube was neglected. In addition to the measurement time, each reactor were completely covered with black cloth, which to prevent the effects of light on the garbage in microbial phase. The experimental apparatus used in this study is shown in Figure 1.

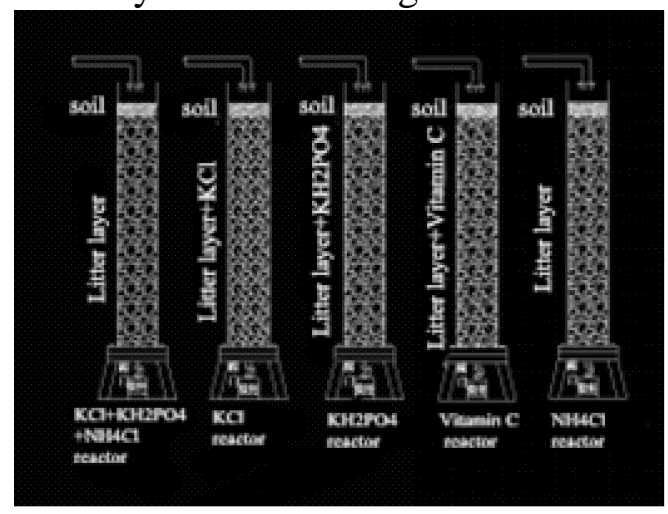

Fig. 1 accelerated life waste degradation test device

Experimental method.The same composition and weight of the living garbage into each reactor.Two of the reactor's garbage does not add nutrients, which used as a contrast reactor.The rest of the reactor respectively on the top of the landfills with watering can spray to join the preparation of the same volume of $1.0 \mathrm{~mol} / \mathrm{L} \mathrm{KCl}, 1.0 \mathrm{~mol} / \mathrm{L} \mathrm{KH}_{2} \mathrm{PO}_{4}, 1.0 \mathrm{~mol} / \mathrm{L} \mathrm{NH} \mathrm{Nl}_{4} \mathrm{Cl}, 1.0 \mathrm{~mol} / \mathrm{L}$ vitamin $\mathrm{C}$ and $1.5 \mathrm{~mol} / \mathrm{L} \mathrm{KCl}+\mathrm{KH}_{2} \mathrm{PO}_{4}+\mathrm{NH}_{4} \mathrm{Cl}\left(\mathrm{KCl}, \mathrm{KH}_{2} \mathrm{PO}_{4}, \mathrm{NH}_{4} \mathrm{Cl}\right.$ 0.5mol $)$.Measuring the height of the reactor's garbage in seven days.After 180 days of experiment, it was determined that the type of nutrient solution can accelerate the degradation rate of the litter and the best effect of nutrients on accelerating the degradation of living garbage.

The $500 \mathrm{~mL}$ of the distilled water is sprayed on the top of the rubbish pile every seven days to simulate the rainfall to produce a landfill leachate.Collect through the beaker of landfill leachate, the determination of COD and ammonia nitrogen.According to the experimental data analysis of the impact of nutrients on the landfill leachate COD and ammonia nitrogen concentration.

\section{Experimental results and discussion}

The effect of nutrients on accelerating the degradation of domestic waste.In the experimental results, the height of the refuse layer in the reactor was changed with the change of the filling time, as shown in Figure 2.

From Figure 2,in the 180 days of the experiment, the degradation rate of the litter layer in the two reactors was almost the same.This effectively illustrates the difference between the effectiveness of the contrast and the degradation rate of the other reactors and the degradation rate of the garbage in the contrast reactor is the reason for the addition of nutrients.From Figure 2 it is also known, the degradation rate of vitamin $\mathrm{C}$ was the fastest, followed by the addition of $\mathrm{KCl}$, and the second is the addition of $\mathrm{KCl}+\mathrm{KH}_{2} \mathrm{PO}_{4}+\mathrm{NH}_{4} \mathrm{Cl}$ mixed nutrient. After that, the $\mathrm{KH}_{2} \mathrm{PO}_{4}$ was added, and the last is the garbage of the contrast reactor with no added nutrients. The experimental results showed that vitamin $\mathrm{C}, \mathrm{KCl}, \mathrm{KH}_{2} \mathrm{PO}_{4}, \mathrm{NH}_{4} \mathrm{Cl}$ can accelerate the degradation rate of garbage, which is a growth factor required for microbial degradation of domestic rubbish (Microorganisms that cannot be synthesized by themselves and are essential for the growth and reproduction of microorganisms ).The nutrient elements used in the experiment were used to accelerate the degradation of the waste. Accelerate the degradation of nutrition elements used in the experiment of effect from good to bad in the order: vitamin $\mathrm{C}>\mathrm{KCl}>\mathrm{KCl}+\mathrm{KH}_{2} \mathrm{PO}_{4}+\mathrm{NH}_{4} \mathrm{Cl}>\mathrm{KH}_{2} \mathrm{PO}_{4}>\mathrm{NH}_{4} \mathrm{Cl}$. 


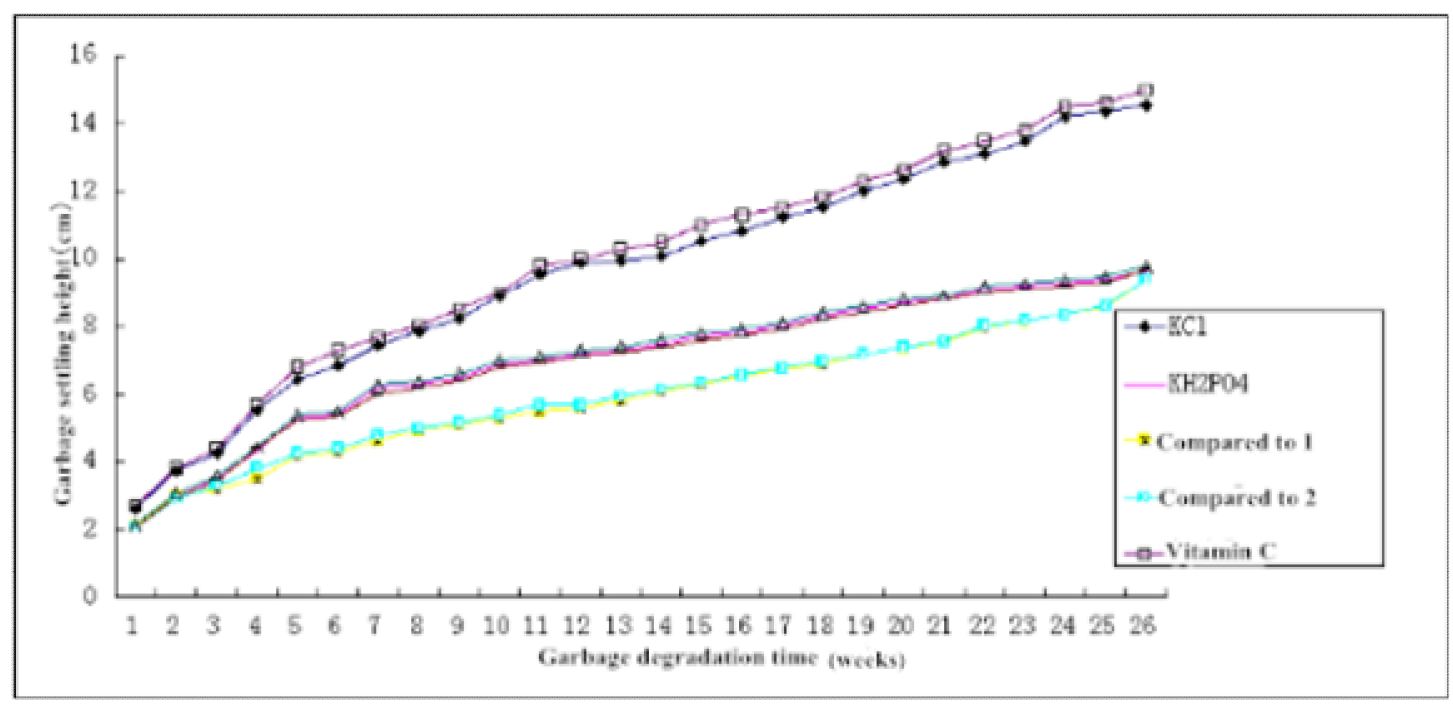

Fig. 2 the change curve of garbage degradation time with the garbage

From the results of this experiment, vitamin $\mathrm{C}, \mathrm{KCl}, \mathrm{KH}_{2} \mathrm{PO}_{4}, \mathrm{NH}_{4} \mathrm{Cl}, \mathrm{KCl}+\mathrm{KH}_{2} \mathrm{PO}_{4}+\mathrm{NH}_{4} \mathrm{Cl}$ can accelerate the degradation rate of living garbage. It is proved that nitrogen, phosphorus, potassium and vitamin $\mathrm{C}$ are the nutrient elements needed for the growth of anaerobic microorganisms. In view of the practical effect of accelerating the degradation of living garbage, which the demand for vitamin $\mathrm{C}$ in the process of anaerobic microorganism in the process of degradation of living garbage is the most urgent.It is also very urgent demand for potassium, greater than the demand for nitrogen and phosphorus. This is mainly because of the high content of organic matter (especially nitrogen content) in the living garbage. With the living garbage anaerobic landfill process, the decomposition of nitrogen organic matter can provide a certain amount of nitrogen and phosphorus, and so the microorganism is not lack of nitrogen, phosphorus or only a small amount of nitrogen,phosphorus.From living garbage components, the anaerobic decomposition basically not to provide microbial potassium, which resulting in anaerobic landfill heap of microbial potassium body element deficiency, thus adding $\mathrm{KCl}, \mathrm{KCl}+\mathrm{KH}_{2} \mathrm{PO}_{4}+\mathrm{NH}_{4} \mathrm{Cl}$ the degradation rate is faster than with $\mathrm{NH} 4 \mathrm{Cl}$ waste body. Adding a mixture of $\mathrm{KCl}, \mathrm{KH}_{2} \mathrm{PO}_{4}, \mathrm{NH}_{4} \mathrm{Cl}$ waste degradation rate is lower than the garbage degradation rate add $\mathrm{KCl}$. Further confirms the microbial demand for potassium is higher than that of nitrogen, phosphorus demand.It may be that the phosphorus element of KH2PO4 is more than the demand for phosphorus, so the effect of accelerating the degradation of the garbage is better than that of the mixed nutrient.

Effects of nutrients on the COD of landfill leachate. Experiments of litter layer in the reactors generate leachate COD concentration with the change of the landfill time as shown in figure 3.

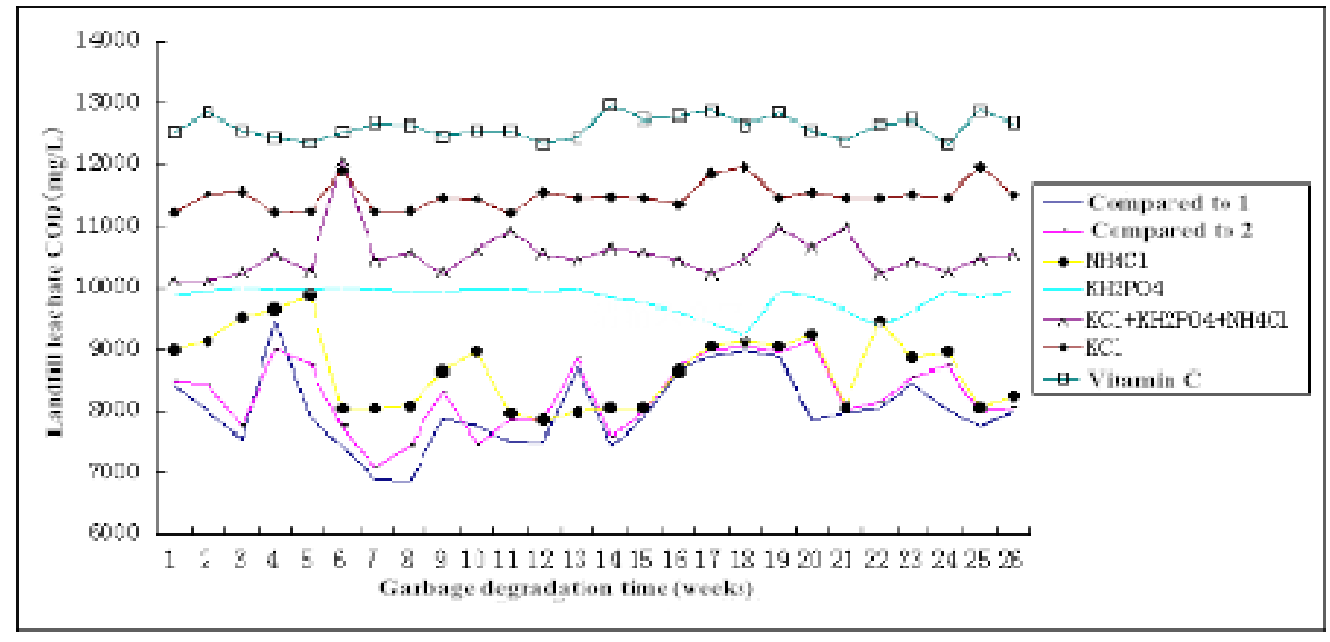

Fig. 3 the change of COD concentration with the time of landfill leachate 
The curve in the figure shows that the two contrast reactor litter layer of leachate COD concentration in 180 days, which are basically the same all the time.this is to show the effectiveness of contrast.Adding vitamin $\mathrm{C}$ layer garbage leachate $\mathrm{COD}$ concentration is highest, followed by adding $\mathrm{KCl}$ waste layer,adding $\mathrm{KCl}+\mathrm{KH}_{2} \mathrm{PO}_{4}+\mathrm{NH}_{4} \mathrm{Cl}$ waste layer,adding the $\mathrm{KH}_{2} \mathrm{PO}_{4}$ of waste layer,adding of $\mathrm{NH}_{4} \mathrm{Cl}$ waste layer,and compare the garbage $\mathrm{COD}$ concentration of the lowest layer.Comparing figure 2 and figure 3 can be found, the garbage decomposition rate faster, generate leachate COD concentration is higher.This is because the more abundant microbial degradation of garbage and the more the number of organic matter degradation. There will be more after the decomposition of small molecule organic matter into the garbage leachate, which resulting in leachate COD concentration increased.The experimental results proved the inference.

Effects of nutrients on the $\mathrm{NH}_{3}-\mathrm{N}$ of landfill leachate. Experiments of litter layer in the reactors generate leachate $\mathrm{NH}_{3}-\mathrm{N}$ concentration with the change of the landfill time as shown in figure 4.

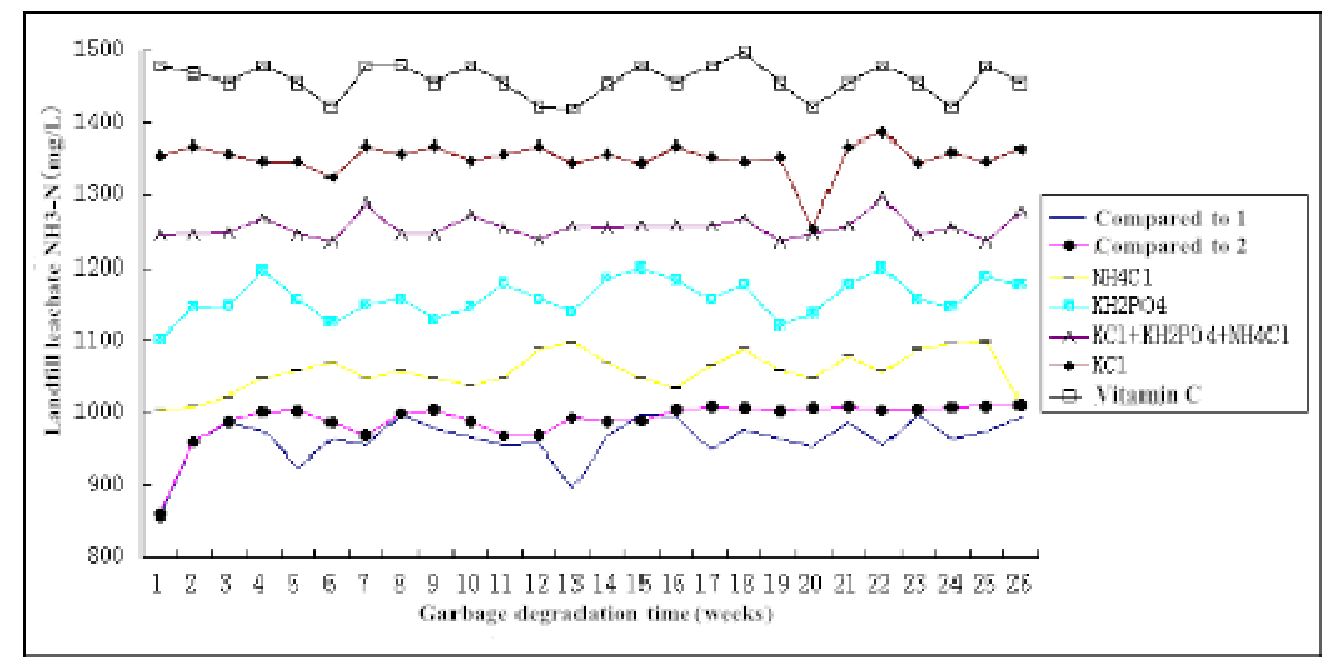

Fig. 4 the change of $\mathrm{NH}_{3}-\mathrm{N}$ concentration with the time of landfill leachate

Comparison figure 3 and figure 4 each curve shows that the change of the landfill leachate ammonia nitrogen and COD of the same law.That is, the faster the garbage and the higher the concentration of COD and the concentration of ammonia nitrogen. The two contrast litter layer ammonia nitrogen concentration change basically the same.This experiment chooses the life rubbish is given priority to with kitchen waste.A lot of nitrogenous organic matter in the kitchen waste.In the decomposition of organic nitrogen most will be converted to ammonia nitrogen, and ammonia in water solubility is very high, so the faster the degradation of the landfill and the higher the concentration of ammonia nitrogen in the leachate.In this experiment, add nutrients litter layer produced by ammonia nitrogen concentration in the range of 1005-1456 mg/L, and the actual of ammonia nitrogen concentration landfill leachate are roughly equal.

\section{Conclusion}

(1)In anaerobic landfill waste added vitamin $\mathrm{C}, \mathrm{KCl}, \mathrm{KH}_{2} \mathrm{PO}_{4}, \mathrm{NH}_{4} \mathrm{Cl}$ and a mixture of $\mathrm{KCl}, \mathrm{KH}_{2} \mathrm{PO}_{4}$, $\mathrm{NH}_{4} \mathrm{Cl}$ were added into anaerobic landfill garbage.. These nutrients to accelerate degradation effect: vitamin $\mathrm{C}>\mathrm{KCl}>\mathrm{KCl}+\mathrm{KH}_{2} \mathrm{PO}_{4}+\mathrm{NH}_{4} \mathrm{Cl}>\mathrm{KH}_{2} \mathrm{PO}_{4}>\mathrm{NH}_{4} \mathrm{Cl}$.

(2)The higher the degradation rate, the higher the COD and the ammonia nitrogen concentration was.

\section{Acknowledgements:}

This work was financially supported by the National Natural Science Foundation of China(No.51208226) . 


\section{References}

[1] DU Juan.Treatment Technologies for Municipal Domestic Waste in China[J].Guangzhou Chemical Industry,2011,39(16):31 32.

[2] Lu Mingdong.The Present State and Trends in Development of Domestic Waste Treatment Technology at home and abroad[J].Popular Science \& Technology,2013,15(166):83 85.

[3] Zhao Miao, Ren Lian Hai, Wang Pan.Analysis of the status quo of China's urban domestic waste disposal technology[J].Journal of Green Science and Technology,2013,12:146 149.

[4] Bin Xiaobei,Li Qian .Summary analysis of disposal status and treatment technology of municipal solid waste at home and abroad[J].Northern Environment,2011,23(10):42 44.

[5] Zheng Siwei.Estimation and Control of Methane Emissions in Landfills[J].Environmental Science and management,2013,38(7):45 49.

[6] Hou Yunfeng. The Present Situation of Treatment Technology for Urban Domestic Waste in china[J]. Chinese resources Comprehensive Utilization ,2012,30(2):50 52. 